\title{
Pengaruh Neuroticism terhadap Emotional Eating
}

\author{
Naufal Fathanah \\ Program Studi S1 Psikologi, Fakultas Ilmu Sosial, Universitas Brawijaya \\ Jl. Veteran, Malang, Jawa Timur, Indonesia 65145 \\ naufathanah@gmail.com \\ Nur Hasanah \\ Program Studi S1 Psikologi, Fakultas Ilmu Sosial, Universitas Brawijaya \\ Research Group Halal and Qualified Industry Development (HAl Q ID) \\ Jl. Semarang No. 5, Malang, Jawa Timur, Indonesia 65145 \\ n.hasanah6874@ub.ac.id
}

Infromasi Artikel

\begin{tabular}{ll}
\hline Tanggal masuk & $19-08-2020$ \\
Tanggal revisi & $05-11-2020$ \\
Tanggal diterima & $01-06-2021$
\end{tabular}

Kata Kunci:

Neuroticism;

Emotional eating;

Dewasa awal.

Keywords:

Neuroticism;

Emotional eating;

Early Adults

\begin{abstract}
Abstrak
Emotional eating adalah perilaku makan sebagai respons dari emosi tertentu yaitu happiness, sadness, anger, dan anxiety. Tujuan dari penelitian ini adalah untuk memahami dan mengetahui pengaruh neuroticism terhadap emotional eating secara simultan dan parsial pada individu dewasa awal. Pada penelitian ini, sampel yang digunakan adalah 199 individu berusia 19-40 tahun yang didapatkan dengan menggunakan teknik accidental sampling. Akat ukur yang digunakan untuk mengukur variabel neuroticism pada penelitian ini adalah Big Five Inventory subskala neuroticism. Untuk mengukur emotional eating, peneliti menggunakan Salzburg Emotional Eating Scale (SEES). Kedua alat ukur tersebut sudah diadaptasi ke Bahasa Indonesia. Dengan menggunakan Simple Multivariate Regression sebagai teknik analisis data, peneliti menyatakan bahwa terdapat pengaruh neuroticism terhadap emotional eating secara simultan sedangkan secara parsial, neuroticism hanya memiliki pengaruh terhadap emotional eating dimensi anxiety. Emosi anxiety dinilai paling dominan di antara emosi negatif yang ada (anxiety, sadness, dan anger) di dalam facet neuroticism pada kaitanya dengan emotional eating. Social facilitation dan impression management dapat menjadi penyebab tidak adanya pengaruh neuroticism terhadap emotional eating dimensi happiness
\end{abstract}

Abstract

Emotional eating is eating behavior in response to certain emotions, namely happiness, sadness, anger, and anxiety. The purpose of this study was to understand and determine the effect of neuroticism on emotional eating simultaneously and partially in early adult individuals. In this study, the sample used was 199 individuals aged 19-40 years who were obtained using accidental sampling technique. The scale used to measure the neuroticism variable in this study is the Big Five Inventory scale of the neuroticism subscale. To measure emotional eating, researchers used the Salzburg Emotional Eating Scale (SEES). Both measuring instruments have been adapted to Indonesian. The data analysis technique used is Simple Multivariate Regression. The results of this study state that there is an effect of neuroticism on emotional eating simultaneously, while partially, neuroticism only has an effect on emotional eating anxiety dimension. Emotional anxiety is considered the most dominant among the negative emotions that exist (anxiety, sadness, and anger) in neuroticism facet in relation to emotional eating. Social facilitation and impression management can be the cause of the absence of the effect of neuroticism on emotional eating happiness dimension. 


\section{PENDAHULUAN}

Memilih dan mengonsumsi makanan merupakan pilihan bagi setiap orang (Hayden, 2009). Selama menjalani kehidupan sehari-hari, manusia tidak akan lepas dari beberapa pilihan makanan yang tidak sehat seperti makanan cepat saji dan makanan yang memiliki kandungan gula atau lemak yang berlebihan. Perilaku makan tersebut akan memberikan dampak yang buruk pada kesehatan yang akan menyebabkan berbagai jenis penyakit seperti diabetes, overweight dan obesitas (Cahanar \& Suhanda, 2006; Swinburn, Caterson, Seidell, \& James, 2004).

Proporsi overweight dan obesitas pada orang dewasa diatas 18 tahun di Indonesia mengalami peningkatan dalam 5 tahun terakhir (Riskesdas, 2018). Pada tahun 2018 proporsi overweight di Indonesia mencapai 13.6, sedangkan untuk proporsi obesitas mencapai 21.8 (Riskesdas, 2018). Peningkatan yang sama juga terjadi pada angka penderita penyakit diabetes. Indonesia menempati peringkat nomor 7 di dunia dalam prevalensi penderita diabetes tertinggi di dunia (World Health Organization (WHO), 2016) dengan estimasi jumlah dari penderita diabetes sebesar 10 juta orang. Angka ini akan terus meningkat seiring dengan meningkatnya angka overweight dan obesitas, mengingat keduanya adalah faktor resiko dari penyakit diabetes (Oroh, Masi, \& Nangge, 2018). Penyakit-penyakit tersebut datang dari perilaku konsumsi makanan yang tidak seimbang, seperti mengonsumsi makanan dengan kadar gula dan lemak yang berlebihan (KEMENKES, 2015).

Perubahan dan transisi dari masa remaja akhir menuju masa dewasa awal mampu mengubah kebiasaan dan rutinitas individu, dimana hal ini juga dapat mengubah perilaku makan suatu individu (Verplanken \& Roy, 2016). Perubahan yang terjadi dalam masa dewasa awal seperti menempuh pendidikan, menikah, berkeluarga, dan bekerja memiliki kaitan dengan tingkat konsumsi makanan yang sehat. Terdapat penelitian yang menyebutkan bahwa ada penurunan kualitas konsumsi makanan disaat suatu individu merantau dan saat individu mulai memasuki dunia kerja (Winpenny et al., 2018).

Saat ini, kebiasaan megonsumsi makanan sehat telah berubah akibat perkembangan ekonomi yang begitu pesat. Hal ini ditandai dengan akses yang semakin mudah terhadap makanan yang tidak sehat dan juga harga yang lebih murah dibandingkan dengan makanan sehat (Henningsen, 2011). Aplikasi berbasis daring seperti Gojek dan Grab memberikan layanan berupa pesan-antar makanan yang dapat dengan mudah diakses oleh mahasiswa seperti Go-food dan Grab food. Individu yang sedang mengerjakan beragam tugas di suatu tempat dapat dengan mudah memesan makanan atau minuman tanpa harus keluar ruangan. Pilihan menu makanan tidak sehat yang dikonsumsi secara berlebihan akan berpotensi membawa penyakit bagi individu (Cahanar \& Suhanda, 2006), terlebih dengan adanya kemudahan mendapatkan makanan tersebut melalui aplikasi daring. Hal ini diduga memiliki dampak kepada perilaku makan individu.

Perilaku makan tidak hanya disebabkan oleh rasa lapar, tetapi juga terdapat faktorfaktor lain yang mempengaruhinya (Nelvi, 2016). Salah satu faktor yang mempengaruhi perilaku makan pada adalah kepribadian, suasana hati, dan cita rasa (Gibney dalam Nelvi, 2016). Maka dari itu, individu mungkin saja menggunakan aplikasi tersebut untuk memesan makanan walaupun tidak merasa lapar, tetapi lebih dikarenakan sedang merasakan emosi negatif, seperti sedih, marah, atau cemas.

Dalam teori eating behavior terdapat tiga dimensi psikologis dari perilaku makan, yaitu emotional eating, restrained eating, dan external eating (van Strien, Frijters, Bergers, \& Defares, 1986). Perilaku makan ini 
memiliki potensi bagi individu overweight dan Obesitas (Kristina Elfhag \& Morey, 2008). Emotional eating adalah keinginan untuk mengonsumsi makanan sebagai respons dari emosi negatif seperti rasa kecewa atau kesepian (Kristina Elfhag \& Morey, 2008). External eating berarti mengonsumsi makanan sebaga respons dari stimulus eksternal makanan seperti aroma dan rasa (van Strien et al., 1986). Restrained eating adalah usaha untuk mengurangi makanan dan kalori untuk mengontrol indeks massa tubuh (Kristina Elfhag \& Morey, 2008).

Emotional eating dan external eating dapat dikatakan sebagai eating style yang bermasalah karena kedua dimensi tersebut berkorelasi positif dengan indeks masa tubuh yang tinggi (Krislina Elfhag \& Linné, 2005) dan konsumsi makanan dengan gula yang berlebih (Kristina Elfhag, Tholin, \& Rasmussen, 2008). Emotional eating juga berkorelasi positif terhadap eating disorders seperti bulimia nervosa (Geliebter \& Aversa, 2003). Beberapa penelitian juga mengatakan bahwa emotional eating selalu dihadapkan dengan emosi negatif seperti depresi, marah, kecewa, rasa cemas dan rasa takut (Arnow, Kenardy, \& Agras, 1995). Masih terdapat perbedaan antara hasil penelitian mengenai restrained eating terutama dalam korelasinya dengan indeks massa tubuh (Krislina Elfhag \& Linné, 2005; Provencher, Drapeau, Tremblay, Després, \& Lemieux, 2003). Dari ketiga dimensi eating behavior tersebut, yang menjadi fokus utama pada penelitian ini adalah emotional eating. Dimensi tersebut dipilih karena memiliki kesamaan dengan salah satu traits kepribadian yang juga didasari oleh afek atau emosi negatif, yaitu neuroticism.

Telah dijelaskan sebelumnya bahwa kepribadian dapat mempengaruhi eating behavior individu. Nilai personality trait seseorang memiliki hubungan dengan berbagai masalah dan penyakit kesehatan seperti diabetes, obesitas, dan tekanan darah tinggi (Deary, Weiss, \& Batty, 2010). Salah satu teori dari personality trait yang paling populer adalah Five Factor Model. Dalam teori tersebut terdapat 5 dimensi personality yaitu conscientiousness, extraversion, openness, agreeableness, dan neuroticism (Costa \& McCrae, 2008). Dari kelima dimensi tersebut, hanya conscientiousness yang mampu memprediksi penyakit dan kesehatan secara konsisten, walaupun dimensi lainnya juga memiliki peran (Goodwin \& Friedman, 2006).

Dari hasil penelitian Goodwin dan Friedman, maka yang menjadi fokus utama dalam penelitian ini adalah neuroticism. Neuroticism adalah personality trait yang memiliki kecenderungan untuk mengalami afek negatif seperti kemarahan, rasa cemas, ketidakstabilan emosi, dan depresi (Widiger \& Oltmanns, 2017). Neuroticism sangat rentan terhadap beberapa bentuk psikopatologi seperti mood, rasa cemas, dan eating disorders (Bagby, R.M; Uliaszek, A.A; Gralnick, T.M et al dalam Widiger \& Oltmanns, 2017).

Personality trait sering dikaitkan dengan eating behavior (Bogg \& Roberts, 2004) dalam hal ini, neuroticism memiliki hubungan positif dengan eating behavior yang tidak sehat, yaitu external eating dan emotional eating (Magee \& Heaven, 2011; Provencher et al., 2008). Pengaruh neuroticism terhadap emotional eating juga didukung dengan definisi yang mirip dari keduanya. Keduanya dipengaruhi dan didasari oleh afek negatif yaitu rasa marah, takut, depresi, kecewa, dan cemas (Arnow et al., 1995; Kristina Elfhag \& Morey, 2008; Widiger \& Oltmanns, 2017).

Individu dengan kecenderungan neuroticism yang tinggi mudah dalam mengalami afek negatif, namun apakah afek negatif tersebut berpengaruh terhadap emotional eating dimana mengonsumsi 
makanan merupakan respons dari afek negatif tersebut?. Dari penjabaran latar belakang tersebut, peneliti bertujuan untuk mengetahui dan memahami pengaruh neuroticism terhadap emotional eating pada individu dewasa awal, baik secara simultan maupun parsial dari tiap dimensi emotional eating. Masa dewasa awal dipenuhi oleh masalah dan ketegangan sosial serta penyesuaian diri pada pola hidup baru (Hurlcok, 2009).

Meule, Reichenberger, \& Blechert (2018) dalam studinya mengatakan bahwa terdapat 4 dimensi dari emotional eating, yaitu happiness, sadness, anger, dan anxiety. Walaupun emotional eating memiliki kaitan yang erat dengan emosi negatif, beberapa penelitian terkini telah memberikan kesimpulan bahwa emosi positif juga memiliki dampak terhadap konsumsi makanan (Cardi, Leppanen, \& Treasure, 2015). Penelitian yang dilakukan oleh Van Strien, Herman, Anschutz, Engels, \& de Weerth (2012) juga memberikan kesimpulan bahwa emosi-emosi tersebut tidak hanya meningkatkan konsumsi makanan namun juga dapat menurunkan konsumsi makanan. Beberapa penelitian tersebut memberikan penjelasan bahwa emosi mampu mempengaruhi perilaku makan, baik meningkatkan ataupun menurunkan tingkat konsumsi makanan.

Hipotesis mayor dalam penelitian ini adalah terdapat pengaruh neuroticism terhadap emotional eating secara simultan, sedangkan terdapat 4 hipotesis minor dalam penelitian ini, yaitu terdapat pengaruh terhadap neuroticism terhadap keempat dimensi emotional eating (happiness, sadness, anger, dan anxiety) secara parsial.

\section{METODE}

Penelitian ini menggunakan metode pendekatan kuantitatif dan merupakan jenis penelitian korelasional. yaitu suatu penelitian untuk mengetahui pengaruh, kaitan, dan tingkat pengaruh antara dua variabel atau lebih tanpa terdapat usaha untuk mempengaruhi salah satu variabel sehingga tidak terdapat manipulasi variabel (Emzir, 2009), dimana dalam penelitian ini yang menjadi variabel bebas adalah neuroticism dan yang menjadi variabel terikat adalah emotional eating dimensi happiness, sadness, anger, dan anxiety.

Populasi yang digunakan dalam penelitian ini adalah individu yang sudah memasuki fase dewasa awal (19-40 tahun) (Hurlcok, 2009). Jumlah sampel yang digunakan dalam penelitian ini berjumlah 199 individu berusia 19-40 tahun.

Teknik sampling yang digunakan pada penelitian ini adalah teknik accidental sampling dimana sampel yang diambil dilakukan secara kebetulan namun tetap mengacu kepada kriteria sampel yang sesuai (Azwar, 2012). Pengumpulan data dilakukan dengan menyebarkan kuesioner yang berisi alat ukur Big Five Inventory (BFI) yang sudah diadaptasi kedalam bahasa dan kultur Indonesia (Ramdhani, 2012) serta alat ukur Salzburg Emotional Eating Scale (SEES) untuk mengukur emotional eating (Meule et al., 2018) melalui google form. Kedua alat ukur tersebut menggunakan skala likert. Pengambilan data dilakukan selama satu minggu di bulan Januari 2020.

Teknik analisis data yang digunakan adalah simple multivariate regression dengan bantuan R program versi 3.6.1 psych package. Teknik ini dipilih untuk menganalisis pengaruh antar variabel.

\section{HASIL}

Gambaran umum subjek penelitian adalah sebagai berikut:

Berdasarkan tabel 1, dapat diketahui bahwa dari keseluruhan subjek yang berjumlah 199, subjek paling banyak berjenis kelamin perempuan (63.45\%) dengan usia paling banyak adalah 21 tahun (35,53\%). Etnis paling banyak adalah Jawa $(78,17 \%)$. Subjek penelitian ini didominasi oleh 
Tabel 1. Gambaran Umum Subjek Penelitian

\begin{tabular}{|c|c|c|c|}
\hline $\begin{array}{l}\text { Data } \\
\text { Demo- } \\
\text { grafis }\end{array}$ & Kategori & Jumlah & $\begin{array}{l}\text { Persent } \\
\text { ase }(\%)\end{array}$ \\
\hline Jenis & Laki-laki & 72 & 36.54 \\
\hline Kelamin & Perempuan & 125 & 63.45 \\
\hline \multirow[t]{7}{*}{ Usia } & 21 & 70 & 35.53 \\
\hline & 19 & 30 & 15.22 \\
\hline & 20 & 27 & 13.70 \\
\hline & 22 & 25 & 12.69 \\
\hline & 25 & 5 & 2.53 \\
\hline & 27 & 5 & 2.53 \\
\hline & $>27$ & 35 & 17.76 \\
\hline \multirow[t]{7}{*}{ Etnis } & Jawa & 154 & 78.17 \\
\hline & Batak & 8 & 4.06 \\
\hline & Sunda & 6 & 3.04 \\
\hline & Tionghoa & 5 & 2.53 \\
\hline & Betawi & 3 & 1.52 \\
\hline & Melayu & 3 & 1.52 \\
\hline & Lain-Lain & 18 & 9.13 \\
\hline \multirow{7}{*}{$\begin{array}{l}\text { Pekerjaan } \\
\text { Utama }\end{array}$} & Mahasiswa/ & 158 & 80.20 \\
\hline & Pelajar & & \\
\hline & $\begin{array}{l}\text { Karyawan/ } \\
\text { Pegawai }\end{array}$ & 33 & 16.75 \\
\hline & Pilot & 1 & 0.50 \\
\hline & Polri & 2 & 1.01 \\
\hline & Wirausaha & 2 & 1.01 \\
\hline & Guru & 1 & 0.50 \\
\hline \multirow[t]{4}{*}{$B M I$} & Gemuk & 18 & 9.13 \\
\hline & Ideal & 104 & 52.79 \\
\hline & Kurang & 21 & 10.65 \\
\hline & Lebih & 54 & 27.41 \\
\hline
\end{tabular}

mahasiswa/pelajar $(80,20 \%)$ dan sebagian besar subjek memiliki $B M I$ yang ideal $(52.79 \%)$.

Hasil pengumpulan data kemudian dikategorisasikan menjadi 3 kategori yaitu rendah, sedang, dan tinggi. Untuk variabel emotional eating, peneliti menggunakan norma kategorisasi sesuai tata aturan yang sudah dibuat oleh peneliti aslinya (Meule et al., 2018) dengan skor rendah memiliki

Tabel 2.

Kategori Subjek variabel neuroticism Neuroticism

\begin{tabular}{lcc}
\hline Kategori & $\begin{array}{c}\text { Jumlah } \\
\text { Subjek }\end{array}$ & Persentase (\%) \\
\hline Rendah & 33 & 16,75 \\
Sedang & 125 & 63,45 \\
Tinggi & 39 & 19,79 \\
\hline
\end{tabular}

Tabel 3.

Kategori Subjek variabel happiness

\begin{tabular}{lcc}
\hline \multicolumn{3}{c}{ Happiness } \\
\hline \multirow{2}{*}{ Kategori } & $\begin{array}{c}\text { Jumlah } \\
\text { Subjek }\end{array}$ & Persentase (\%) \\
\hline Rendah & 20 & 10,05 \\
Sedang & 70 & 35,17 \\
Tinggi & 109 & 54,77 \\
\hline
\end{tabular}

Tabel 4.

Kategori Subjek variabel sadness Sadness

\begin{tabular}{lcc}
\hline Kategori & $\begin{array}{c}\text { Jumlah } \\
\text { Subjek }\end{array}$ & Persentase (\%) \\
\hline Rendah & 105 & 52,76 \\
Sedang & 25 & 12,56 \\
Tinggi & 69 & 34,67 \\
\hline
\end{tabular}

Tabel 5.

Kategori Subjek variabel anger

\begin{tabular}{lcc}
\hline \multicolumn{3}{c}{ Anger } \\
\hline Kategori & $\begin{array}{c}\text { Jumlah } \\
\text { Subjek }\end{array}$ & Persentase (\%) \\
\hline Rendah & 111 & 55,77 \\
Sedang & 54 & 27,13 \\
Tinggi & 34 & 17,08 \\
\hline
\end{tabular}

Tabel 6.

Kategori Subjek variabel anxiety

\begin{tabular}{lcc}
\hline \multicolumn{3}{c}{ Anxiety } \\
\hline Kategori & $\begin{array}{c}\text { Jumlah } \\
\text { Subjek }\end{array}$ & Persentase (\%) \\
\hline Rendah & 148 & 74,37 \\
Sedang & 32 & 16,08 \\
Tinggi & 19 & 9,54 \\
\hline
\end{tabular}

makna makan lebih sedikit dari biasanya, skor sendang memiliki makna makan sebanyak biasanya, dan skor tinggi memilki makna makan lebih banyak dari biasanya.

Berdasarkan tabel 2, 3, 4, 5, dan 6 dapat diketahui bahwa kategorisasi tiap variabel memiliki hasil yang beragam. Pada variabel neuroticism (tabel 2), mayoritas subjek yang berada pada kategori sedang berjumlah 125 (63.45\%). Pada variabel happiness (tabel 3), 
jumlah subjek paling banyak berada pada kategori tinggi yaitu berjumlah 109 (54.77\%), Pada variabel sadness (tabel 4), jumlah subjek paling banyak ada pada kategori rendah, yaitu berjumlah 105 (52.76\%). Pada variabel anger (tabel 5), jumlah subjek terbanyak berada pada kategori rendah, yaitu berjumlah 111 (55.77\%). Pada variabel anxiety (tabel 6), jumlah subjek terbanyak berada pada kategori rendah, yaitu berjumlah 148 (74.37\%). Dari hasil tersebut dapat diaktakan bahwa mayoritas subjek mendapatkan nilai tinggi pada emotional eating dimensi emosi positif (happiness), dan mendapatkan nilai rendah pada emotional eating dimensi emosi negatif (sadness, anger, dan anxiety).

Uji asumsi yang dilakukan pada penelitian ini adalah uji normalitas dan uji linearitas, dimana data yang didapatkan pada penelitian ini tidak terdistribusi dengan normal karena seluruh variabel memiliki $p$ value dibawah 0.05 , sedangkan hasil dari uji linearitas menunjukan bahwa hanya variabel neuroticism dan anxiety yang menunjukan hasil linear, sedangkan variabel lainnya tidak, seperti yang terlihat pada tabel 7 dan 8 .

Tabel 7.

Uji Normalitas

\begin{tabular}{lll}
\hline \multicolumn{1}{c}{ Variabel } & F-Statistic & \multicolumn{1}{c}{ p-value } \\
\hline Neuroticism & 0.076 & 0.006 \\
Happiness & 0.199 & $2.2 \mathrm{e}-16$ \\
Sadness & 0.078 & 0.004567 \\
Anger & 0.162 & $5.254 \mathrm{e}-14$ \\
Anxiety & 0.115 & $9.1 \mathrm{e}-07$ \\
\hline
\end{tabular}

Tabel 8.

Uji linearitas antar variabel

\begin{tabular}{|c|c|c|c|}
\hline Variabel & F-Statistic & p-value & Keterangan \\
\hline $\begin{array}{l}\text { Neuroticism } \\
\text { dan } \\
\text { Happiness }\end{array}$ & 0.941 & 0.333 & $\begin{array}{l}\text { Tidak } \\
\text { Linear }\end{array}$ \\
\hline $\begin{array}{l}\text { Neuroticism } \\
\text { dan Sadness }\end{array}$ & 0.262 & 0.608 & $\begin{array}{l}\text { Tidak } \\
\text { Linear }\end{array}$ \\
\hline $\begin{array}{l}\text { Neuroticism } \\
\text { dan Anger }\end{array}$ & 0.354 & 0.552 & $\begin{array}{l}\text { Tidak } \\
\text { Linear }\end{array}$ \\
\hline $\begin{array}{l}\text { Neuroticism } \\
\text { dan Anxiety }\end{array}$ & 4.652 & 0.032 & Linear \\
\hline
\end{tabular}

Tabel 9. Analisis data secara simultan

\begin{tabular}{lcc}
\hline \multicolumn{1}{c}{ Variabel } & $\begin{array}{c}\text { Multiple } \\
\text { R-Squared }\end{array}$ & p-value \\
\hline $\begin{array}{l}\text { Neuroticism } \\
\text { dan } \\
\text { emotional } \\
\text { eating }\end{array}$ & 0.055 & 0.024 \\
\hline
\end{tabular}

Tabel 10. Analisis data secara parsial

\begin{tabular}{lccc}
\hline \multicolumn{1}{c}{ Variabel } & $\mathrm{B}$ & $F$-Statistic & $p$-value \\
\hline $\begin{array}{l}\text { Neuroticism } \\
\text { dan }\end{array}$ & -0.739 & 0.941 & 0.333 \\
Happiness & & & \\
\hline $\begin{array}{l}\text { Neuroticism } \\
\text { dan Sadness }\end{array}$ & 0.253 & 0.262 & 0.608 \\
\hline $\begin{array}{l}\text { Neuroticism } \\
\text { dan } \text { Anger }\end{array}$ & 0.385 & 0.354 & 0.552 \\
\hline $\begin{array}{l}\text { Neuroticism } \\
\text { dan } \text { Anxiety }\end{array}$ & -1.195 & 4.652 & 0.032 \\
\hline
\end{tabular}

Terdapat beberapa perdebatan mengenai seberapa diperlukannya uji asumsi sebelum uji hipotesis dilakukan. Menurut Azwar (2001), analisis data tetap dapat dilakukan terlepas dari terpenuhi atau tidaknya asumsiasumsi yang bersangkutan dan teknik analisis statistika yang digunakan untuk mengambil keputusan masih dapat digunakan tanpa harus didahului oleh uji asumsi. Alsa (2001) juga mengatakan bahwa pengabaian uji asumsi tidak berpengaruh banyak terhadap hasil dan kesimpulan dari penelitian yang dilakukan. Berdasar keterangan dari kedua ahli tersebut, maka peneliti memutusukan untuk tetap menggunkanan uji parametrik terlepas dari hasil uji asumsi yang sudah dilakukan. Analisis data menggunakan simple multivariate regression mendapatkan hasil bahwa terdapat pengaruh antara neuroticism dan emotional eating secara signifikan dengan nilai multiple $R$-Squared sebesar 0.055 yang berarti seluruh dimensi dalam emotional eating mampu menjelaskan pengaruhnya dengan neuroticism secara simultan sebesar $5.5 \%$, sedangkan hanya terdapat satu pengaruh antar variabel penelitian saja yang mampu menerima 
hipotesis yaitu pengaruh variabel neuroticism terhadap anxiety secara parsial. Neuroticism memprediksi emotional eating anxiety sebesar $\mathrm{B}=-1.195$ dengan effect size sebesar $1.8 \%, \mathrm{R}^{2}=0.0181$ dan signifikansi sebesar $0.032(\mathrm{p}<0.05)$. Dapat dilihat pada tabel 10 .

\section{PEMBAHASAN}

Tujuan utama dari dilakukanya penelitian ini adalah untuk mengetahui apakah terdapat pengaruh neuroticism terhadap emotional eating (happiness, sadness, anger, anxiety). Hasil dari analisis data yang sudah dilakukan menunjukan bahwa terdapat pengaruh neuroticism terhadap emotional eating yang signifikan secara simultan sehingga hipotesis mayor dapat diterima. Namun pada hipotesis minor, hanya terdapat satu pengaruh antar variabel neuroticism terhadap emotional eating yang mampu menerima hipotesis minor, yaitu pengaruh antara variabel neuroticism terhadap anxiety.

Hasil analisis data mendapatkan hasil bahwa Neuroticism memprediksi emotional eating anxiety sebesar $\mathrm{B}=-1.195$ dengan effect size sebesar $1.8 \%, R^{2}=0.018$ dan signifikansi sebesar $0.032(p<0.05)$ sehingga memiliki bukti yang cukup kuat untuk mampu menerima hipotesis dan dapat disimpulkan bahwa variabel neuroticism memiliki pengaruh yang signifikan terhadap emotional eating anxiety. Arah dari pengaruh antar kedua variabel tersebut adalah negatif, yang berarti individu dengan nilai neuroticism yang tinggi akan mengonsumsi makan lebih sedikit dari biasanya saat sedang mengalami emosi anxiety dan begitu sebaliknya, individu dengan nilai neuroticism yang rendah akan mengonsumsi makan lebih banyak saat sedang mengalami emosi anxiety.

Hasil dari ketiga pengaruh antar variabel penelitian lainnya yaitu neuroticism dengan happiness, neuroticism dengan sadness, dan neuroticism dengan anger tidak mampu menerima hipotesis karena ketiganya memiliki nilai $p$-value diatas 0.05 sehingga dapat dikatakan bahwa ketiga pengaruh antar variabel tersebut belum memiliki bukti yang cukup kuat untuk mampu menerima hipotesis minor dan dapat dikatakan tidak memiliki pengaruh yang signifikan.

Dari hasil kategorisasi juga didapatkan hasil yang sama, yaitu mayoritas responden melaporkan bahwa mereka makan lebih sedikit saat sedang mengalami emosi anger dan anxiety. Perbedaan baru terdapat pada kategorisasi emosi happiness dan sadness, dimana pada penelitian yang dilakukan oleh Meule et al., (2018) mayoritas responden makan lebih banyak saat sedang mengalami emosi sadness dan makan sebanyak biasanya saat sedang mengalami emosi happiness, sedangkan dari hasil yang didapatkan pada penelitian ini responden makan lebih banyak saat sedang mengalami emosi happiness dan makan lebih sedikit saat sedang mengalami emosi sadness.

Hasil analisis data pada penelitian ini menyatakan bahwa terdapat pengaruh neuroticism terhadap emotional eating anxiety sebesar $\mathrm{B}=-1.195$ dengan effect size sebesar $1.8 \%, \mathrm{R}^{2}=0.0181$ dan signifikansi sebesar $0.032(\mathrm{p}<0.05)$. Semakin tinggi skor anxiety yang dimiliki oleh individu, maka semakin sedikit konsumsi makanan yang akan dikonsumsi oleh individu tersebut saat sedang merasa tegang, cemas, khawatir, gugup, dan tidak tenang. Sebanyak 148 dari 199 responden mendapatkan skor emotional eating dimensi anxiety yang rendah. Hal ini dapat dikarenakan terdapat hubungan yang sangat kuat antara neuroticism dan anxiety (Johansson \& Ölund, 2017; Widiger \& Oltmanns, 2017). Hal ini menunjukan bahwa emosi anxiety lah yang paling dominan diantara emosi negatif yang ada (anxiety, sadness, dan anger) di dalam facet neuroticism pada kaitanya dengan emotional eating. 
Tidak terdapatnya pengaruh neuroticism terhadap emotional eating dimensi happiness dapat disebabkan oleh beberapa hal, yaitu karena happiness memang tidak ada dalam facet neuroticism atau juga dapat disebabkan oleh social facilitation (Herman, Roth, \& Polivy, 2003) dan kultur yang ada. Mengonsumsi makanan sering digunakan sebagai sarana untuk memberikan penghargaan kepada diri sendiri dan erat kaitanya dengan bersenang-senang atau perayaan atas suatu pencapaian tertentu seperti acara ulang tahun dan pernikahan. Saat menghadiri acara tersebut, seorang individu kemungkinan akan mengubah konsumsi makananya demi mendapatkan kesan tertentu dari orang lain, hal ini disebut impression management (Vartanian, Herman, \& Polivy, 2007). Kehadiran orang lain mampu mempengaruhi konsumsi makanan seorang individu (Herman et al., 2003). Hal ini yang diperkirakan menyebabkan tidak adanya pengaruh antara neuroticism dan emotional eating dimensi happiness.

Pada penelitian ini terdapat keterbatasan: bahwa penelitian ini tidak bisa digeneralisasi ke dewasa awal secara umum, karena subjek penelitian didominasi oleh dewasa awal dengan status mahasiswa sedangkan sisanya diwakili selain mahasiswa dengan komposisi yang tidak merata.

\section{KESIMPULAN}

Dari penelitian yang sudah dilakukan, terdapat beberapa hasil yang mampu disimpulkan. Berikut adalah beberapa kesimpulan mengenai penelitian pengaruh antara neuroticism dan emotional eating:

1. Terdapat pengaruh neuroticism terhadap emotional eating secara simultan.

2. Tidak terdapat pengaruh neuroticism terhadap emotional eating happiness.
3. Tidak terdapat pengaruh neuroticism terhadap emotional eating sadness.

4. Tidak terdapat pengaruh neuroticism terhadap emotional eating anger.

5. Terdapat pengaruh neuroticism terhadap emotional eating anxiety.

Penelitian selanjutnya diharapkan mampu mengeksplorasi emotional eating pada kelompok subjek yang lain terutama selain mahasiswa, mengingat beban, tugas dan tanggung jawab akan mempengaruhi stress yang tentunya berpengaruh terhadap emotional eating subjek.

\section{DAFTAR RUJUKAN}

Alsa, A. (2001). Kontroversi Uji Asumsi Dalam Statistik Parametrik. Buletin Psikologi, 9(1), 18-22. https:// doi.org/10.22146/bpsi.7437

Arnow, B., Kenardy, J., \& Agras, W. S. (1995). The emotional eating scale: The development of a measure to assess coping with negative affect by eating. International Journal of Eating Disorders, 18(1), 79-90. https:// doi.org/10.1002/1098-108X(199507) $18: 1<79::$ AIDEAT2260180109>3.0.CO;2-V

Azwar, S. (2001). Asumsi-Asumsi Dalam Inferensi Statistika. Buletin Psikologi, 9 (1), 8-17. https://doi.org/10.22146/ bpsi.7436

Beaton, D. E., Bombardier, C., Guillemin, F., \& Ferraz, M. B. (2000). Guidelines for the Process of Cross-Cultural Adaptation of Self-Report Measures. SPINE, 25(4), 225-230. https:// doi.org/10.1080/000163599428823

Bogg, T., \& Roberts, B. W. (2004). Conscientiousness and health-related behaviors: A meta-analysis of the leading behavioral contributors to 
mortality. Psychological Bulletin, 130

(6), 887-919. https:// doi.org/10.1037/0033-2909.130.6.887

Cahanar, P., \& Suhanda, I. (2006). Makan Sehat, Hidup Sehat. https://doi.org/ https://doi.org/10.3929/ethz-b000238666

Cardi, V., Leppanen, J., \& Treasure, J. (2015). The effects of negative and positive mood induction on eating behaviour: A meta-analysis of laboratory studies in the healthy population and eating and weight disorders. Neuroscience and Biobehavioral Reviews, 57, 299-309. https://doi.org/10.1016/ j.neubiorev.2015.08.011

Costa, P. T., \& McCrae, R. R. (2008). The revised NEO personality inventory (NEO-PI-R). In The SAGE Handbook of Personality Theory and Assessment: Volume 2 - Personality Measurement and Testing (pp. 179-198). https:// doi.org/10.4135/9781849200479.n9

Deary, I. J., Weiss, A., \& Batty, G. D. (2010). Intelligence and personality as predictors of illness and death: How researchers in differential psychology and chronic disease epidemiology are collaborating to understand and address health inequalities. Psychological Science in the Public Interest, Supplement, 11(2), 53-79. https:// doi.org/10.1177/1529100610387081

Dovey, M. T. (2010). Eating Behaviour. Retrieved from https://www.ucl.ac.uk/ iehc/research/behavioural-sciencehealth/resources/questionnaires/eatingbehaviour-questionnaires/\#fcq

Elfhag, Krislina, \& Linné, Y. (2005). Gender differences in associations of eating pathology between mothers and their adolescent offspring. Obesity Research,
13(6), 1070-1076. https:// doi.org/10.1038/oby.2005.125

Elfhag, Kristina, \& Morey, L. C. (2008). Personality traits and eating behavior in the obese: Poor self-control in emotional and external eating but personality assets in restrained eating. Eating Behaviors, 9(3), 285-293. https://doi.org/10.1016/ j.eatbeh.2007.10.003

Elfhag, Kristina, Tholin, S., \& Rasmussen, F. (2008). Consumption of fruit, vegetables, sweets and soft drinks are associated with psychological dimensions of eating behaviour in parents and their 12-year-old children. Public Health Nutrition, 11(9), 914923. $\quad$ https://doi.org/10.1017/ S1368980008002371

Geliebter, A., \& Aversa, A. (2003). Emotional eating in overweight, normal weight, and underweight individuals. Eating Behaviors, 3(4), 341-347. https://doi.org/10.1016/S1471-0153(02) 00100-9

Goldberg, L. R. (1992). The Development of Markers for the Big-Five Factor Structure. Psychological Assessment, Vol. 4(1), 26-42.

Goodwin, R. D., \& Friedman, H. S. (2006). Health status and the five-factor personality traits in a nationally representative sample. Journal of Health Psychology, 11(5), 643-654. https:// doi.org/10.1177/1359105306066610

Heaven, P. C. L., Mulligan, K., Merrilees, R., Woods, T., \& Fairooz, Y. (2001). Neuroticism and conscientiousness as predictors of emotional, external, and restrained eating behaviors. International Journal of Eating Disorders, 30(2), 161-166. https:// 
doi.org/10.1002/eat.1068

Henningsen, M. (2011). Dietary habits in adolescence related to sociodemographic factors, physical activity and self-esteem. Department of Social Work and Health Science, Faculty of Social Science and Technology Management, Norwegian University of Science and Technolog, 1 -54 .

Herman, C. P., Roth, D. A., \& Polivy, J. (2003). Effects of the Presence of Others on Food Intake: A Normative Interpretation. Psychological Bulletin, 129(6), $\quad$ 873-886. https:// doi.org/10.1037/0033-2909.129.6.873

Hurlcok, E. B. (2009). Psikologi Perkembangan: Suatu Pendekatan Sepanjang Rentang Kehidupan (R. Max, Ed.). Jakarta: Erlangga.

Johansson, M., \& Ölund, A. (2017). Thinking about thinking - a study of anxiety, neuroticism and Need for Cognition.

John, O. P., \& Srivastava, S. (1999). The BigFive Trait Taxonomy: History, Measurement, and Theoretical Perspectives. Arthritis and Rheumatism, 64(2), 327-338. https:// doi.org/10.1002/art.33369

Keller, C., \& Siegrist, M. (2015). Does personality influence eating styles and food choices? Direct and indirect effects. Appetite, 84, 128-138. https:// doi.org/10.1016/j.appet.2014.10.003

KEMENKES. (2015). Kenali Kebiasaan Penyebab Diabetes. Kementrian Kesehatan Indonesia, 1-2.

Magee, C. A., \& Heaven, P. C. L. (2011). Big -Five personality factors, obesity and 2year weight gain in Australian adults. Journal of Research in Personality, 45 (3), 332-335. https://doi.org/10.1016/ j.jrp.2011.02.009

McCrae, R. R., \& Costa, P. T. (1995). Domains and facets: hierarchical personality assessment using the revised NEO personality inventory. Journal of Personality Assessment, 64 (1), 21-50.

McCrae, R. R., \& Costa, P. T. (1999). A fivefactor theory of personality. In Handbook of Personality: Theory and Research (2nd ed). New York: Guilford.

Meule, A., Reichenberger, J., \& Blechert, J. (2018). Development and preliminary validation of the Salzburg Emotional Eating Scale. Appetite, 120(February), 442-448. https://doi.org/10.1016/ j.appet.2017.10.003

Nelvi, R. (2016). Pengaruh Antara Dimensi Kepribadian Big Five Dengan Perilaku Makan Pada Mahasiswa UIN Suska Riau Di Pekanbaru Riau Relationship Between The Big Five Personality and Eating Behaviors on Students at UIN Suska Riau In Pekanbaru Riau. Psikologi, 12(1), 47-52.

Oroh, W., Masi, G., \& Nangge, M. (2018). Pengaruh Obesitas Dengan Kejadian Diabetes Melitus Di Wilayah Kerja Puskesmas Ranomut Kota Manado. Keperawatan, 6(1), 1-6.

Provencher, V., Bégin, C., Gagnon-Girouard, M. P., Tremblay, A., Boivin, S., \& Lemieux, S. (2008). Personality traits in overweight and obese women: Associations with BMI and eating behaviors. Eating Behaviors, 9(3), 294302 . https://doi.org/10.1016/ j.eatbeh.2007.10.004

Provencher, V., Drapeau, V., Tremblay, A., Després, J. P., \& Lemieux, S. (2003). Eating behaviors and indexes of body composition in men and women from the Québec family study. Obesity 
Research, 11(6), 783-792. https:// doi.org/10.1038/oby.2003.109

Ramdhani, N. (2012). Adaptasi Bahasa dan Budaya Inventori Big Five. Jurnal Psikologi, 39(2), 189-207.

Riskesdas. (2018). Riset Kesehatan Dasar 2018. Kementrian Kesehatan Republik Indonesia, 1-100. https://doi.org/1 Desember 2013

Shaheen, F., Jahan, M., \& Shaheen, S. (2014). Role of Personality Factors in Experiencing Psychological Distress among Adolescents. International Journal of Education and Psychological Research, 3(1).

Swinburn, B., Caterson, I., Seidell, J., \& James, W. (2004). Diet, nutrition and the prevention of excess weight gain and obesity. Public Health Nutrition, 7 (1a), 123-146. https://doi.org/10.1079/ phn2003585

van Strien, T., Frijters, J. E. ., Bergers, G. P. ., \& Defares, P. B. (1986). The Dutch Eating Behavior Questionnaire (DEBQ) for Assesment of Restrained, Emotional, and External Eating Behavior. Archives of Pharmacal Research, 5(2), 295-315. https:// doi.org/10.1007/BF02973988

Van Strien, T., Herman, C. P., Anschutz, D. J., Engels, R. C. M. E., \& de Weerth, C. (2012). Moderation of distress-induced eating by emotional eating scores. Appetite, 58(1), 277-284. https:// doi.org/10.1016/j.appet.2011.10.005

Vartanian, L. R., Herman, C. P., \& Polivy, J. (2007). Consumption stereotypes and impression management: How you are what you eat. Appetite, 48(3), 265-277. https://doi.org/10.1016/ j.appet.2006.10.008

Verplanken, B., \& Roy, D. (2016).
Empowering interventions to promote sustainable lifestyles: Testing the habit discontinuity hypothesis in a field experiment. Journal of Environmental Psychology, 45, 127-134. https:// doi.org/10.1016/j.jenvp.2015.11.008

Wakhid, A., \& Trimawati. (2018). Studi Deskriptif Perilaku Emotional Eating Mahasiswa Yang Mengerjakan Skripsi Di Universitas Ngudi Waluyo Ungaran. Jurnal SMART Keperawatan Sekolah Tinggi Ilmu Kesehatan (STIKes) Karya Husada Semaran, 5(1), 52-60.

Widiger, T. A., \& Oltmanns, J. R. (2017). Neuroticism is a fundamental domain of personality with enormous public health implications. World Psychiatry, 16(2), 144-145. https:// doi.org/10.1002/wps.20411

Winpenny, E. M., van Sluijs, E. M. F., White, M., Klepp, K. I., Wold, B., \& Lien, N. (2018). Changes in diet through adolescence and early adulthood: longitudinal trajectories and association with key life transitions. The International Journal of Behavioral Nutrition and Physical Activity, 15(1), 86. https://doi.org/10.1186/s12966-0180719-8

World Health Organization (WHO). (2016). Diabetes Fakta dan Angka. Epidemiological Situation. 